\title{
Chapter 6 \\ Decline and Response? Lifecycle Change and Housing Estates in Birmingham, England
}

\begin{abstract}
Alan Murie
Abstract This chapter discusses mass public housing estates in England and uses Birmingham to illustrate how estates have changed. In British cities, large housing estates built between the 1950s and 1970s are particularly associated with flats and tower blocks. They formed an important part of public housing, but failures in design, construction, management and maintenance meant that they often also damaged its status and reputation. Estates have changed over time and this Chapter, highlights internal and external influences and demolition, privatisation and regeneration. These influences have been layered on each other and interacted to generate different outcomes in different places. Some estates and properties from this era have proved popular and successful, but in other cases questions have arisen about their construction, suitability for disadvantaged communities and continuing role. The failures of some estates and of their regeneration are likely to continue to generate demands for demolition and substantial funding for their redesign.
\end{abstract}

Keywords Birmingham • England - Council housing · Privatisation Regeneration $\cdot$ Residualisation

\subsection{Mass Housing in England}

British public housing, built between the 1950s and 1970s, mainly by local authorities, was heavily influenced by modernist architecture and industrialised building systems. It introduced new divisions, related to dwelling form, type, location and estate layout, within an already substantial council housing sector. Public housing built before this phase was high quality, high status and popular. It provided for households with housing need: demand was high and rents and processes determining access often excluded the lowest income groups and recent

\footnotetext{
A. Murie $(\bowtie)$

The Centre for Urban and Regional Studies, University of Birmingham, Birmingham, UK e-mail: a.s.murie@bham.ac.uk

D. B. Hess et al. (eds.), Housing Estates in Europe, The Urban Book Series, https://doi.org/10.1007/978-3-319-92813-5_6
} 
migrants. Both these estates and the later mass estates were built as single tenure council estates. This determined how access was negotiated and this, distinctive layouts and property types, established them as coherent neighbourhoods. Estates built from the mid-1950s onwards proved less resilient. Their popularity was often undermined and attempts to halt decline were not always effective.

Government subsidies had enabled councils to build over 1 million dwellings in England and Wales between 1919 and 1939 with the highest level of completions $(104,000)$ achieved in 1927/28. When the outbreak of war in 1939 halted housebuilding, councils already provided over $10 \%$ of housing. Public sector housebuilding recommenced rapidly after 1945 and increased government subsidies reflected its importance in post-war economic reconstruction and the welfare state. Between 1945 and 1951 public sector housebuilding accounted for over 80\% of houses built: completions in England and Wales reached 92,000 in 1946 and 186,000 in 1948. They peaked at 221,000 in 1954 (Holmans 1987). By 1953, 2,400,000 dwellings were rented from councils or new towns in England and Wales $-19 \%$ of dwellings. Almost all were traditionally built, family houses (mainly three-bedroom houses in suburban areas) with few flats. The key planning and architectural influences were garden cities rather than modernism. Council housing was superior to most private sector dwellings and attractive to affluent white- and blue-collar workers, but largely inaccessible to poorer households. Housing costs were lower in poorer quality, private rented housing, mostly subject to rent control.

Following success in reducing post-war housing shortages, the focus of policy shifted, from the mid-1950s, to clearing and replacing slum housing, without increasing urban sprawl. This meant rehousing people from private sector slum housing-lower income households, older people and households without children. Councils changed what they built. Government, the construction industry and building professionals promoted modernist designs and industrialised building techniques as a 'technological short cut' (Dunleavy 1981) to enable more to be done quickly, and government subsidies offset the higher costs of building high. This helped to persuade local authorities to set aside views that flats were costly and unpopular. Various types of mass housing, using unfamiliar building systems, with different layouts and environments, were built on inner-city and peripheral sites. By the mid-1960s, councils increased their use of industrialised building and off-site prefabrication, even though the basis for their promotion was sometimes superficial and misleading (Cantle 1986). By 1965, flats comprised 52\% of public sector housebuilding and continued to account for over 50\% until 1973 (Cooney 1974).

In sum, government and its partners supported an experiment to facilitate council house building that altered the balance of dwelling sizes, introduced unfamiliar designs and types of housing and estate layouts in different locations, for different populations. Most of this modern housing was initially welcomed as a dramatic improvement on the slum housing it replaced, but its reputation was soon damaged. The catalyst is generally regarded as the 1968 gas explosion at Ronan Point, a tower block in the London Borough of Newham. Design faults meant that this explosion caused a partial collapse and six people were killed. But criticisms of high costs that achieved negligible increases in densities, of physical and mental health problems 
and about safety, social, aesthetic and other issues meant that government had already planned to reduce subsidies, and local authorities reduced their investment in high flats after 1967.

Accounts of what happened to estates over their lifecycle identify various influences (Hall et al. 2005a). Mass estates had some different dynamics from traditional housing estates. Smaller dwellings, housing smaller (younger and older) households, tended to have higher turnover. Other 'internal' lifecycle factors (demographic changes and the need to replace materials when they fail) applied as in other estates. But some mass estates had significant design and construction faults: the need for remediation emerged more quickly and required more challenging and expensive solutions. In addition, 'external' factors that affected estates included how residualisation of social renting (linked both with economic and housing changes) narrowed the social base of the tenant population and contributed to a spiral of decline.

In England, both internal and external factors affected mass estates. Although generally popular at the outset, many estates were becoming unpopular by the 1980s. Residents were critical of the appearance and environment on estates and of management and maintenance: communal parts of buildings were often poorly designed and easily damaged; open space was unused and poorly maintained. Some system-building techniques had defects that contributed to water penetration, condensation, infestation and inadequate and expensive heating; a long list of physical problems emerged (Cantle 1986). There were concerns about unfavourable effects on families with children, isolation affecting older and other residents, and higher levels of crime and anti-social behaviour. Unpopularity and high turnover were likely where there was poor access to employment; people in employment often preferred other estates and tenants who obtained employment sometimes moved away. High levels of vandalism, vacancy and turnover reflected the pattern of decline, physical defects and unpopular environments. Initial problems and emerging unpopularity generated a second wave of instability, making estates even more difficult to live in and manage.

Mass housing estates slipped towards the bottom of the hierarchy of value and choice within council housing. The status of public housing also declined generally as economic changes and higher unemployment after the 1970s left more households with no alternative other than renting and, as the private rented sector continued to shrink, were more dependent on public housing. Bargaining power and capacity to wait determined who was offered attractive public housing: those with least bargaining power were steered towards the least popular dwellings and estates. Mass public housing estates were among the least desirable, residual parts of an increasingly residual tenure. Poorer people became concentrated in unpopular estates and this partly explained failures to improve estates.

By this stage, the post-war consensus over expanding council housing had been overtaken by political competition to promote homeownership, and later, agendas to reduce the public sector and public expenditure. Council housing had played a steadily increasing role between 1919 and 1981. It provided $25 \%$ of all dwellings in England in 1961 and $28 \%$ in 1971 and 1981. But funding for council house building had dried up by the mid-1980s, there was an increasing backlog of 
disrepair and better quality council housing was a target for privatisation that was popular and generated capital receipts to fund general government expenditure (Forrest and Murie 1990). Public housing stock declined in size and this meant reduced staffing. It also meant there were fewer older properties with low outstanding debt that could cross subsidise properties needing higher expenditure on management, maintenance and repair. Some council housing was also transferred to housing associations, which, along with councils, formed a social rented sector increasingly providing welfare housing for people in crisis rather than high-quality housing for a mixed population. In 1981, this social rented sector provided $31 \%$ of dwellings in England. Its share fell to 23\% in 1991, 20\% in 1992 and 17\% in 2011 and 2016.

Estates spiralling downwards often required major, disruptive and costly investment, but government was unwilling to commit to this. As resources were not forthcoming, low-cost alternatives were favoured-including local lettings schemes under which low demand properties were made available to a wider population, not otherwise eligible for them. This could signal failure and exacerbate high turnover. Although restrictions on management and maintenance expenditure limited capacity to address problems, decentralisation and other local strategies to improve management were adopted. Other approaches included the sale of whole blocks and estates to private developers and housing trusts for refurbishment, involving different levels of demolition.

Until the mid-1980s, government concern about deprived neighbourhoods and inadequate housing largely focussed on inner-city private housing. But difficulties in public housing estates attracted attention and additional funding for selected estates through the Priority Estates Project (1979-1987), the Urban Housing Renewal Unit and its successor Estate Action (1985-1994), Housing Action Trusts (1988-2007), the Estate Renewal Challenge Fund (1995-2000) and Housing Market Renewal (2002-2011). These programmes largely funded investment in dwellings and the physical environment but later programmes and the Single Regeneration Budget (1994-2008) and New Deal for Communities (1998-2010) placed greater emphasis on employment and community. Policies to encourage transfers of council housing to housing associations were also actively pursued from the mid-1980s onwards - partly because transfers enabled access to private finance and, through this, to increased investment in new and existing social housing. These various initiatives helped to make some estates more attractive. Difficulties in letting properties were also relieved by population growth and new demand from refugees, asylum seekers and other migrants. As housing shortages increased it became easier to let less attractive housing - albeit often to households with the most problems and least choice.

Undeniably, government's privatisation policies affected strategies to improve mass estates. When the Right to Buy (2016) introduced higher discounts to encourage sales of flats, government had not fully anticipated the consequences (Murie 2016). Sales and subsequent resales left blocks of flats with mixed ownership: a mix of public and private owners, including absentee private landlords. The leasehold system in England appeared to cope with this but there were 
continuing concerns over levels of service charges; privatisation complicated the process and increased costs where demolition or major refurbishment was planned, and questions arose about where responsibilities related to health and safety rested.

Between 2001 and 2010, government adopted a Decent Homes Policy to raise standards and improve energy efficiency across tenures, but additional funding to enable council housing to reach this higher standard was only available where councils transferred their stock to housing associations or adopted new organisational arrangements such as Arms Length Management Organisations (ALMOs) and Tenant Management Organisations (TMOs). Although councils responded to this agenda in different ways, the social rented sector outperformed other tenures in improving its stock to the Decent Homes Standard.

\subsection{Birmingham}

The city of Birmingham, the largest UK local authority, with a population fluctuating around one million, built 30,000 council dwellings by 1930 and 50,000 by 1939 - almost all single-family, suburban houses. The city was reluctant to build flats that were associated with saving costs and lowering standards: the few flats it built were unpopular (Sutcliffe 1974; Sutcliffe and Smith 1974). The outbreak of war in 1939 halted housing construction, but when Birmingham restarted building after 1945, council completions on land that was already owned, using existing plans, increased rapidly: 18,000 council dwellings were completed between 1945 and 1953, rising from 413 in 1946 to a peak of 4,774 in 1952 (Sutcliffe and Smith 1974; 226-8). This reduced the council's reserves of building land and, by 1949, in spite of continuing reservations about their suitability, more flats were planned. The switch to slum clearance and higher government subsidies to offset the higher costs of building flats persuaded the council to build different dwelling types and designs in different locations. Municipal building increased (over 4,000 dwellings completed within the city boundary in both 1965 and 1966) and the proportion of flats and maisonettes in buildings of three or more storeys also increased (from 4\% in 1951 , to $75 \%$ in 1957) and remained high (85\% in 1961; 77\% in 1965) although with fewer high blocks.

Birmingham constructed 417 high-rise blocks and 60,897 municipal dwellings between 1953 and 1973. Table 6.1 refers to nine Housing Market Areas identified by the city council (Fig. 6.1). Most dwellings built in this period were in peripheral and suburban areas: almost a third in the South West (Northfield, Longbridge and Kings Norton) but almost 1-in-10 built on slum clearance sites around the city centre. Flats and maisonettes accounted for two out of every three dwellings completed. Over $50 \%$ of dwellings had fewer than three bedrooms. Most flats had one or two bedrooms, while most existing and new houses had three bedrooms (Table 6.2). The new estates in this period were usually extensions of existing estates or new areas of fewer than 2,000 dwellings, although there were some larger new estates including Castle Vale. 
Table 6.1 New council dwellings built in Birmingham, 1953-1973: location. Source City of Birmingham

\begin{tabular}{l|l|r}
\hline & \multicolumn{2}{l}{ Total stock } \\
\cline { 2 - 3 } & Number & $\%$ \\
\hline City Centre & 5989 & 9.8 \\
\hline East & 3886 & 6.4 \\
\hline Eastern Periphery & 7510 & 12.3 \\
\hline North West & 6221 & 10.2 \\
\hline Northern Periphery & 1006 & 1.7 \\
\hline Northern Suburbs & 2292 & 3.8 \\
\hline South West & 19388 & 31.8 \\
\hline Suburban Ring North & 7463 & 12.3 \\
\hline Suburban Ring South & 5802 & 9.5 \\
\hline Total & 60897 & 100 \\
\hline & &
\end{tabular}

\subsection{Estates at the Outset}

The first tenants of mass housing estates included households which differed from traditional 'affluent working-class' council tenants. There were more low-income and non-family households, including both older and younger single-person and two-adult households. Although precise statistics are not available, research provides an authoritative account of access to housing (Rex and Moore 1967). In the 1960s, Birmingham was the most prosperous part of Britain after the South East, and attracted immigrants from Britain and beyond. There was excessive demand for council housing, which comprised the best quality, affordable housing in the city, yet priority for council housing went to households displaced by the massive slum clearance programme. While some 'immigrant' households were rehoused from slum clearance areas, minority ethnic groups generally lived outside areas scheduled for redevelopment (Henderson and Karn 1987; 6). A wider section of the population could access council housing but the poorest households-black and minority ethnic groups and recent immigrants-were often excluded, were systematically disadvantaged by the management of slum clearance and allocation processes, and remained in private, inner-city housing.

\subsection{Decline and Fall?}

After the 1960s, changing demography, higher unemployment, the decline of manufacturing and greater income inequalities affected competition for housing in Birmingham. There were changes in housing allocation policy and practice and wider housing policy. Changes in tenure structure and differentiation within tenures further affected patterns of access and the roles of different neighbourhoods. The era following mass public housing construction was marked by promotion of mass 


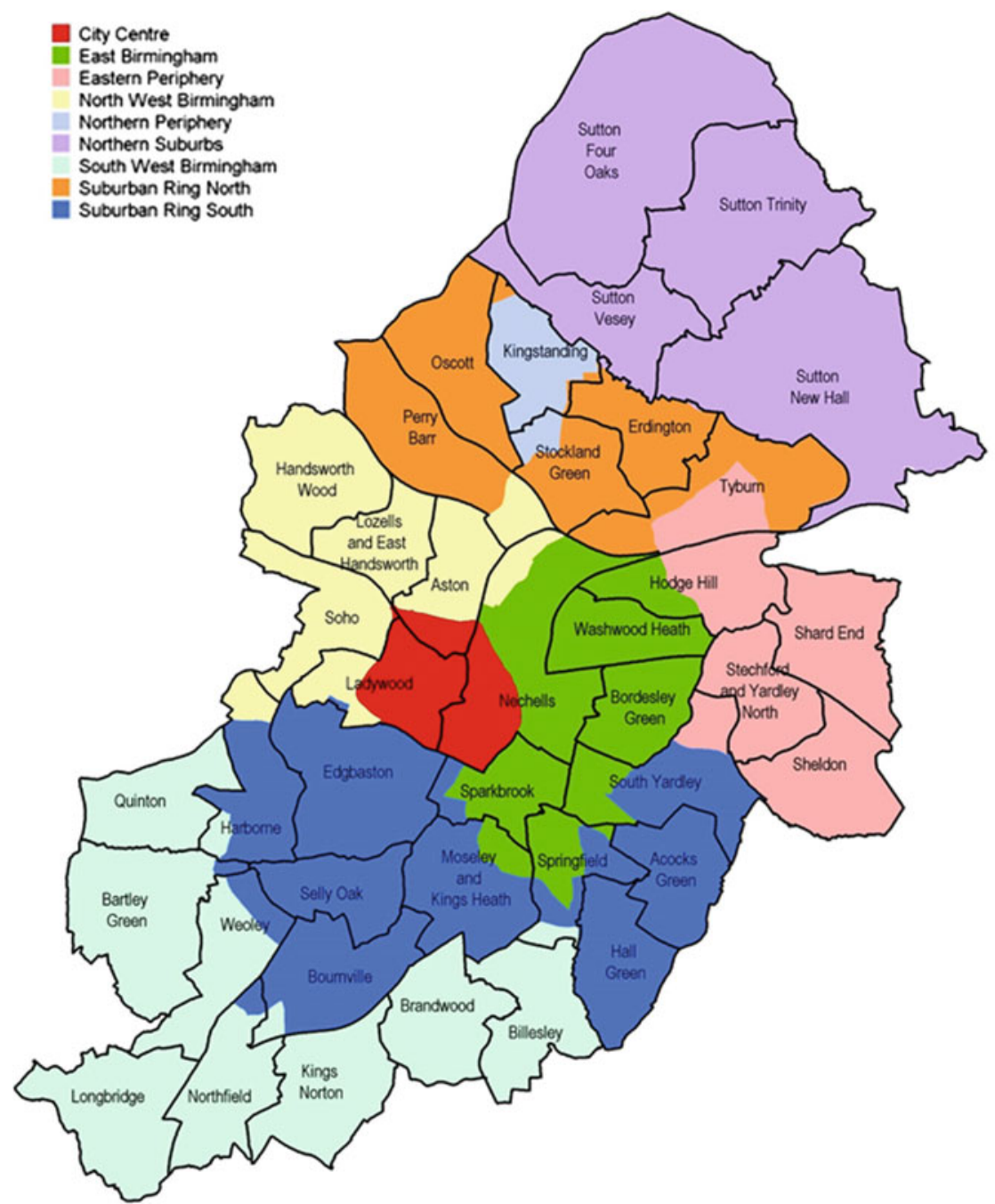

This map is reproduced from Ordnance Survey material with the permission of Ordnance Survey on behalf of the Controller of Her Majesty's Stationery Office $\odot$ Crown copyright. Birmingham City Council, 100021326, 2004

Fig. 6.1 Wards and housing market area boundaries, June 2004, Source City of Birmingham

home ownership. The reputation, quality and resources for council housing declined and being excluded from council housing no longer had the same connotations.

New council house building declined from the mid-1970s and almost ceased within a decade. At the same time, sales of council houses to sitting tenants increased. In 1966, 41\% of dwellings in Birmingham were council owned but this 
Table 6.2 New council dwellings built in Birmingham, 1953 to 1973: size and type

\begin{tabular}{|c|c|c|c|c|c|c|c|}
\hline \multicolumn{7}{|c|}{ Number of bedrooms } & \multirow[t]{2}{*}{ Total } \\
\hline & bedsit & 1 & 2 & 3 & $4+$ & Unknown & \\
\hline Bungalow & 41 & 1988 & 107 & 24 & & & 2160 \\
\hline Flat & 833 & 12360 & 15390 & 4518 & 6 & 19 & 33126 \\
\hline House & & & 1747 & 13967 & 2082 & 265 & 18061 \\
\hline Maisonette & & 16 & 1287 & 6178 & 56 & & 7537 \\
\hline Other & & 1 & 10 & & 1 & 1 & 13 \\
\hline Total & 874 & 14365 & 18541 & 24687 & 2122 & 285 & 60897 \\
\hline
\end{tabular}

Source City of Birmingham

declined to $38 \%$ in $1977,35 \%$ in $1981,27 \%$ in $1991,19 \%$ in 2001 and $15 \%$ in 2011. Although the housing association stock had grown from $4 \%$ in 1981 to $9 \%$ in 2011, the combined social rented stock had declined enormously. The council housing stock was smaller and older and higher rents and restrictions on expenditure reduced its attractiveness.

The 1970 s to 1990 s saw slum clearance superseded by urban renewal: older private housing was improved and repaired rather than demolished and replaced. Changes to council housing allocation rules also meant that black and immigrant households were no longer excluded. The number of black households in council housing increased from 1,500 in 1969 to over 6,000 in 1977 (Henderson and Karn 1987). In $1975,10 \%$ of the population of the city were 'immigrants' but they still formed but only $3 \%$ of council tenants. Although not excluded from council housing, it remained more difficult for households of Asian and West Indian heritage to access council housing; and where they became council tenants, it was more likely to be in inner-city areas irrespective of stated preferences. The combination of bureaucratic processes and household preferences $(90 \%$ of immigrants preferred inner-city locations) left ethnic minorities (especially Asian households) concentrated in inner-city areas. Peripheral estates were less attractive to ethnic minority groups than inner-city estates where they were over-represented (Rex and Tomlinson 1981). This divergence in the ethnic mix between inner and outer city estates affected bureaucratic allocation decisions and household choices and consolidated, segregation between estates. The debate shifted to questions about concentration (segregation) and unequal access to different estates in the city.

Explanations for patterns of choice and residence were complicated as homeownership became more accessible. New community-based urban renewal policy channelled public expenditure towards inner-city neighbourhoods and private housing and this, as well as policies affecting access to council housing, affected competition for housing. Some households - including those from minority ethnic groups-preferred inner-city areas where they had family and social networks. These were no longer areas of last resort, neglected by public expenditure. Urban renewal improved opportunities for inner-city residents including a growing population of working-class owner-occupiers. 
Subsequent analysis of Birmingham shows a complex pattern of cross-tenure deprivation replacing the 1960s pattern of exclusion from council housing. In 1991, ethnic minority households were less likely to be in council housing than white households but there was variation between minority groups. Black African households $(0.3 \%$ of the population) were more than twice as likely to be council tenants than their population share would suggest (and four times more likely to be in council flats). The ratios for other groups were Black Caribbean, $4.7 \%$ of the population with a probability of being council tenants of 1.4; Bangladeshi, 1.3\% and 0.7; Pakistani, 6.9\% and 0.4; and Indian, 5.3\% and 0.2. Birmingham did not have the polarised pattern associated with some British cities with social renting for marginalised groups and homeownership for affluent households. Less affluent households lived in both private and council housing, in inner-city and peripheral locations: ethnic minority households were concentrated in inner-city private housing with low-income white households in peripheral council estates (Lee and Murie 1997; 27, 48; 2002).

Access to council housing was also affected by privatisation. Birmingham pioneered sales of council houses to sitting tenants, at discounted prices but flats were not sold until after legislation providing a Right to Buy (1980). Both before and after 1980, Birmingham disproportionately sold attractive traditional houses in low-density suburban areas, to affluent, long-standing, middle-aged tenants (Forrest and Murie 1990). The lowest rates of sale were among properties built between 1954 and 1963 and between 1964 and 1973: the highest rates among pre-war properties (Jones and Murie 1999). Mass housing was further residualised. Fewer relets of better council houses meant new applicants were steered towards flats and maisonettes in less popular estates.

By the mid-1980s, it had become evident that Birmingham had to address problems associated with mass housing estates and especially flats with spalling concrete and loose mosaic. In view of the failures elsewhere, the approach that Birmingham adopted to refurbishment is important. The city established and kept under regular review, its standard for refurbishment: repairing concrete, removing loose mosaic, covering with mineral fibre insulation secured by wire mesh that held everything in place and providing the key for a render overcoat. The system could cope with variable thickness to mask any undulations and imperfections. It ensured that insulation was dry and allowed different colours and designs - enabling residents to influence the final appearance. The city considered panel systems, but the structural problems encountered, fire safety and cost considerations and the first blocks considered being 'out of square', favoured the render-based solution.

Alongside this standard for refurbishment, the council increased local management and maximised funding from government programmes. The council was reluctant to follow central government's encouragement of stock transfers. It transferred stock, with tenants' agreement, in Castle Vale and the Central Estates in order to access additional funding. But a proposal by the Labour-controlled council for a city-wide stock transfer was rejected by tenants in 2002. Subsequently, both Conservative and Labour-controlled councils rejected further significant stock transfers and sought to reach the Decent Home Standard through asset 
management. This involved evaluation of the costs of refurbishing properties to achieve the standard. Where modelling indicated that rental income over 30 years would be less than the investment needed plus the costs of management and maintenance, consideration was given to alternative strategies, including demolition. The council worked with housing associations (including new community-based associations) and private sector partners to modify or demolish unsustainable estates. The strategy took account of capacity to provide for homeless and larger households and of poverty traps. By 2009, the council had established its own delivery vehicle for new homes for rent and sale (Birmingham Municipal Housing Trust). This contributed by building new homes - within limits presented by subsidy arrangements and grants from the Homes and Communities Agency.

By 2016 , over $20 \%$ of all properties built by Birmingham city council between 1953 and 1973 and over $40 \%$ of maisonettes and over $25 \%$ of flats had been demolished (excluding stock transferred before demolition). Demolitions were proportionately highest in the North West, Northern Periphery and South West. Some $30 \%$ of council housing from this period had also been sold. All estates developed some tenure mix but sales were uneven: about $68 \%$ of houses from this period had been sold but only $21 \%$ of maisonettes and $9 \%$ of flats. Privatisation meant that a higher proportion of the remnant council sector comprised flats. Demolitions and sales together had dramatically changed mass estates. By 2016, less than half the mass housing built in the Eastern periphery, North West and South West areas was still there and still council owned (Table 6.3). The stock was least reduced in the City Centre and the East, North and South suburban rings.

Table 6.3 New council housing built in Birmingham, 1953 to 1973: demolished or sold by area.

\begin{tabular}{|c|c|c|c|c|c|}
\hline \multirow{2}{*}{$\begin{array}{l}\text { Housing } \\
\text { market areas }\end{array}$} & \multirow{2}{*}{$\begin{array}{l}\text { Total public } \\
\text { housing built }\end{array}$} & \multirow{2}{*}{$\begin{array}{l}\text { Public housing } \\
\text { demolished by } 1.4 .16\end{array}$} & \multicolumn{3}{|c|}{ Remaining Dwelling Stock } \\
\hline & & & Total & $\begin{array}{l}\text { Privately owned } \\
\text { (sold by } 31.12 .15 \text { ) }\end{array}$ & $\begin{array}{l}\text { Council } \\
\text { rented }\end{array}$ \\
\hline City Centre & 5989 & 494 & 5495 & 814 & 4581 \\
\hline East & 3886 & 458 & 3428 & 786 & 2642 \\
\hline $\begin{array}{l}\text { Eastern } \\
\text { Periphery }\end{array}$ & 7510 & 1589 & 5921 & 2398 & 3523 \\
\hline North West & 6221 & 1949 & 4272 & 1243 & 3029 \\
\hline $\begin{array}{l}\text { Northern } \\
\text { Periphery }\end{array}$ & 1006 & 269 & 737 & 206 & 531 \\
\hline $\begin{array}{l}\text { Northern } \\
\text { Suburbs }\end{array}$ & 2292 & 339 & 1953 & 764 & 1189 \\
\hline South West & 19388 & 4919 & 14469 & 4805 & 9664 \\
\hline $\begin{array}{l}\text { Suburban } \\
\text { Ring North }\end{array}$ & 7463 & 1032 & 6431 & 1943 & 4668 \\
\hline $\begin{array}{l}\text { Suburban } \\
\text { Ring South }\end{array}$ & 5802 & 653 & 5149 & 1332 & 3817 \\
\hline Total & 60897 & 12350 & 48547 & 14882 & 33665 \\
\hline
\end{tabular}

Source City of Birmingham 


\subsection{The Central Estates}

A case study of five adjacent estates in central Birmingham informs the rest of this chapter. It draws on research and observation over more than 10 years (Hall et al. 2003, 2005b; Rowlands and Murie 2009). The Central Estates were built in the 1950s and 1960s, on land cleared following demolition of high-density housing built without modern amenities and often with outside toilets and washing facilities. Figures 6.2,6.3a, b present images typical of housing in the area, scheduled for slum clearance. By the 1950 s, these predominantly private rented dwellings were affected by poor maintenance and in some places by wartime bomb damage. Their original design and physical deterioration meant they failed to reach minimum fitness standards for healthy housing.

The new estates that replaced slum housing reflected the political and professional enthusiasm for towers in the park, one- and two-bedroom flats, maisonettes and high-rise blocks. The estate layout was a compromise: previous roads were retained with limited new landscaping for tower blocks in green spaces. There were new community facilities although budgetary constraints and services nearby restricted these. Figures 6.4 and 6.5 present positive images of the new estate-a new shopping precinct and a children's paddling pool. Many of the first residents of the Central Estates had previously lived in the neighbourhood and new dwellings were initially popular. By the mid-1990s, however, the management and maintenance of properties and green spaces had largely failed. The paddling pool in Fig. 6.4 no longer existed, and the shops in Fig. 6.5 were mostly empty. The Central Estates were among the most deprived in the city, with high turnover and vacancy rates and poor local facilities, including schools and shops. Estate Action and other funding had enabled some refurbishment but residents felt they were repeatedly overlooked and demanded investment in the neighbourhood. Residents protested about 'The Slum Quarter of Birmingham', outside the city council offices, on a major road route into the city adjacent to the estates (Fig. 6.6a, 6.3b) and elsewhere.

Faced with protests, the city council, with residents' support, bid for Government funding for regeneration under the Estates Renewal Challenge Fund (ERCF). Once this bid was approved and there was a promise of funds, an offer to residents was prepared setting out what was proposed for each part of the estate including demolition, details of refurbishment, proposals for new housing, other property development and new parks. The bid and offer emphasised local priorities and tenant demands rather than conforming to bidding guidelines. It would have been less costly and more comfortable for government if more refurbishment had been proposed with less demolition and new build. The offer was subject to a ballot and residents voted to accept it, having also secured an undertaking from the council to reinvest any receipts from sales of land and property within the area, back in the area. Following the ballot, approval was given to the payment of grant and to the transfer of the council housing that was a condition for payment. Residents decided against working with an existing housing association and Optima Community Association was established with an unprecedented level of tenant 


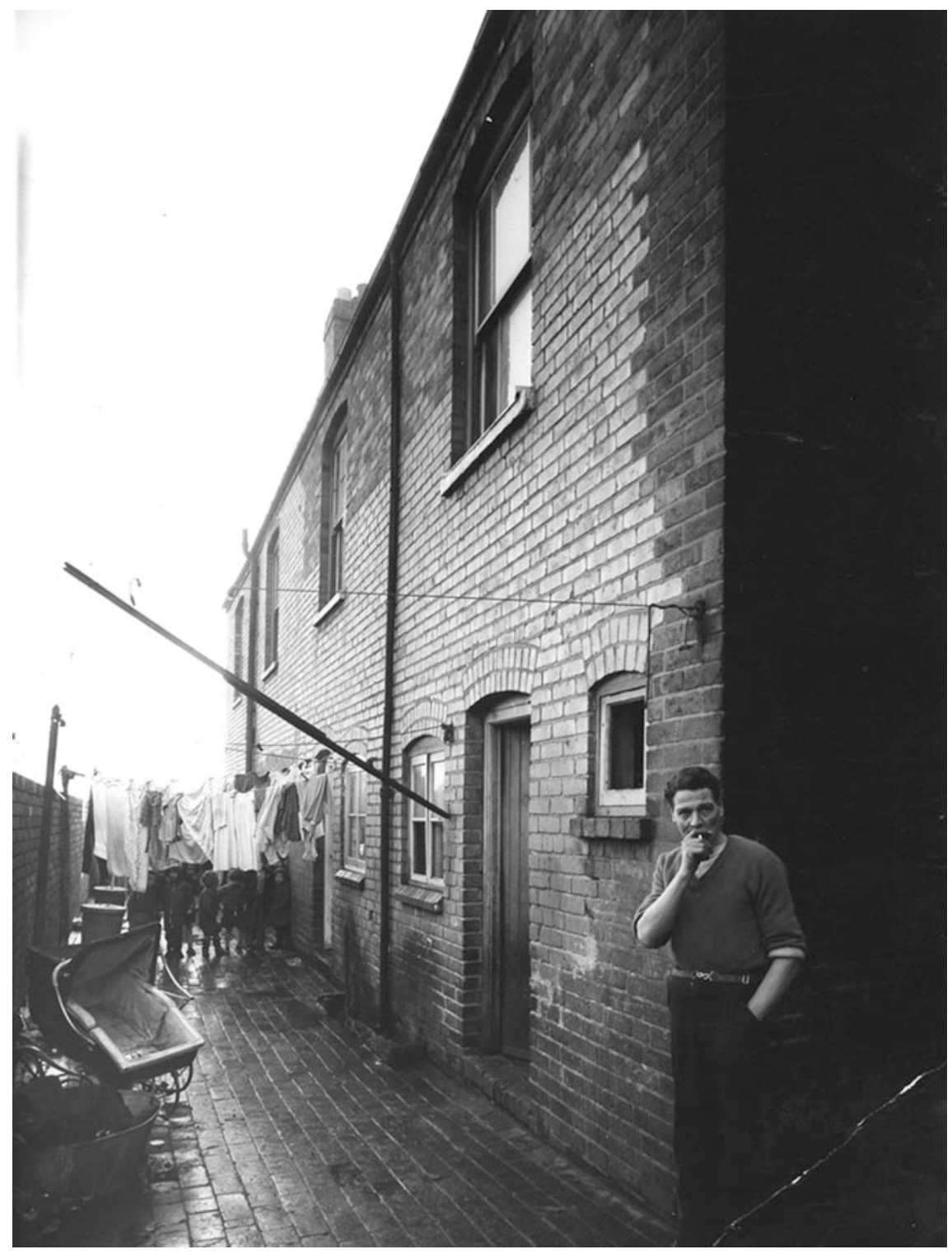

Fig. 6.2 Rear entries to Victorian terraced housing, 1950s, Birmingham. Source Birmingham Library Archives and Optima Community Association, used with permission

participation - seven tenant Board members elected by tenants, three council nominees and five 'independents'.

The Central Estates had some 2,900 council dwellings with 5\% sold under the Right to Buy. The regeneration programme envisaged 1,400 properties being 
(a)

(b)

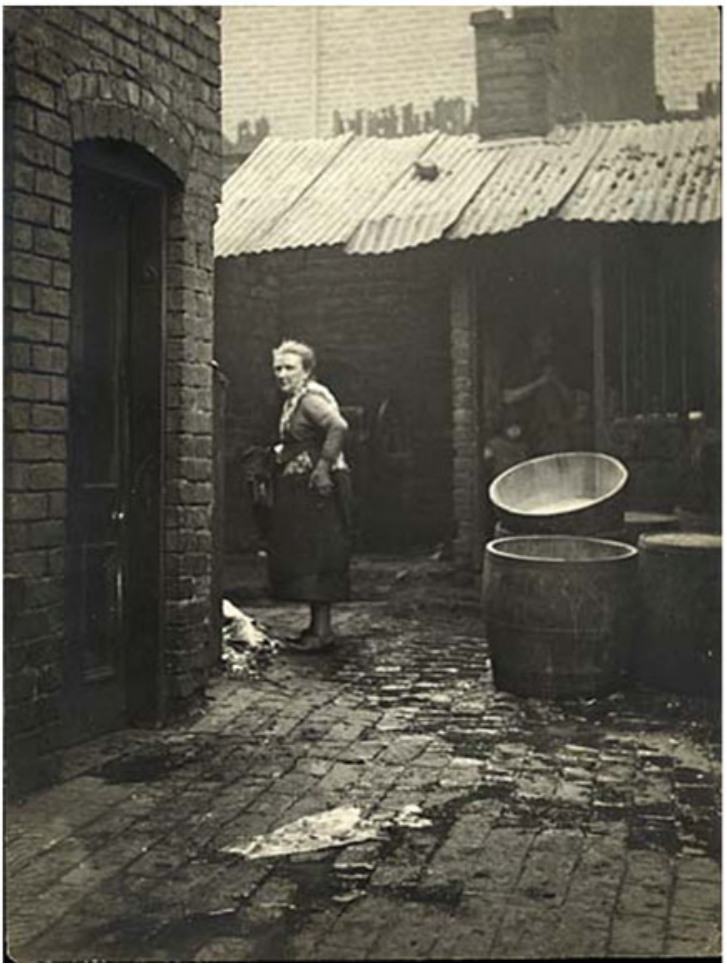

Fig. 6.3 a Streetscape of typical slum properties before clearance, Birmingham $\mathbf{b}$ Rear yard of slum property before clearance, Birmingham. Source Birmingham Library Archives and Optima Community Association, used with permission 


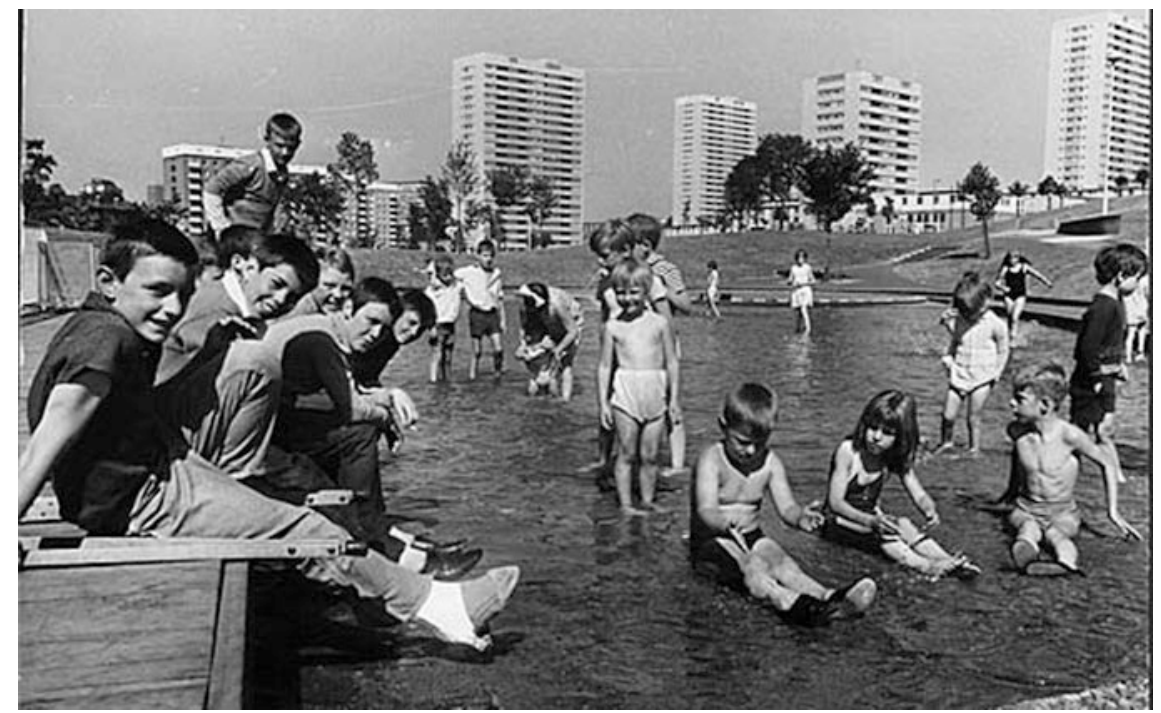

Fig. 6.4 A short-lived paddling pool among towers in the park, 1960s, Lee Bank, Birmingham. Source Birmingham Library Archives and Optima Community Association, used with permission

demolished, 1,400 refurbished and over 2,500 new homes in different tenures (including 550 affordable, predominantly social rented, housing). Refurbishments involved modernisation of kitchens and bathrooms, updating of heating systems, replacement of windows, external cladding and insulation-all improving energy efficiency and meeting the Decent Home standard. Regeneration involved redesigning the estate with changes to levels and road layouts, two new, linked parks replacing the unused green space that had existed around tower blocks, two further small parks, new community facilities (including a health centre, school and community centre) and commercial premises (offices, shops and hotels). What was proposed transformed the look and feel of the estates. Major landmark tower blocks were demolished (including Haddon Tower in Fig. 6.7), while others were refurbished to a high standard. These included the highest two blocks (the 32-storey Sentinels) where new windows and exterior cladding, rewiring, new bathrooms and kitchens and new lifts and entry arrangements to improve security were involved (Fig. 6.8). At the heart of the estates, Fig. 6.9 shows remaining refurbished towers alongside a large area where demolitions facilitated significant work shifting earth to change levels for new mixed-tenure housing built around new parks.

The investment in these estates was substantial: in Birmingham, only the Housing Action Trust funding for Castle Vale was comparable. Funding for 


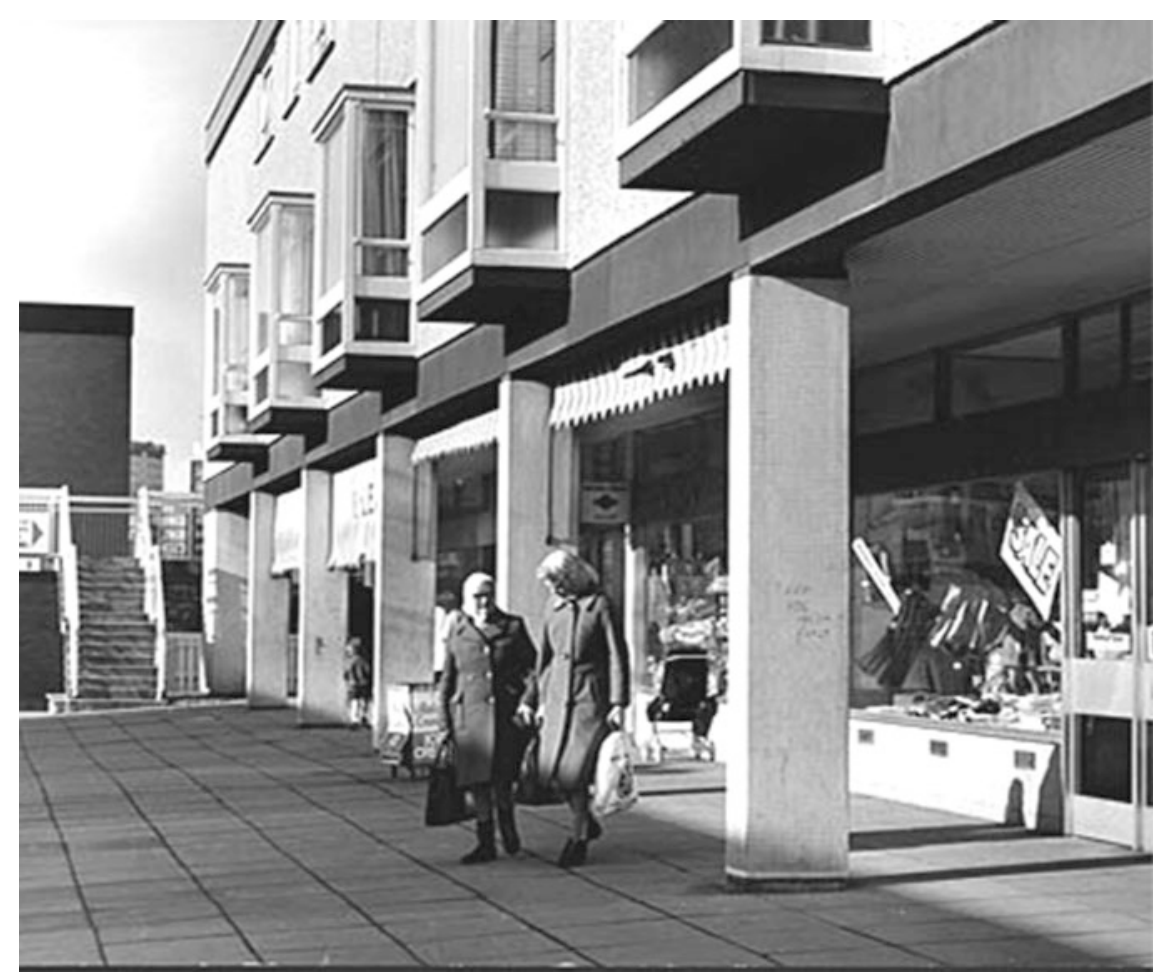

Fig. 6.5 Shopping opportunities in the housing estate, Lee Bank, Birmingham. Source Birmingham Library Archives and Optima Community Association, used with permission

clearance and demolition on the Central Estates exceeded $£ 12$ million: $£ 50$ million for refurbishment of social housing and $£ 83$ million for new social housing. The initial ERCF grant exceeded $£ 46$ million and included over $£ 4$ million for social and economic regeneration. Sales of land and property generated a further $£ 20$ million for reinvestment in the area. These figures exclude investment to build some 700 private dwellings in the first 10 years and a further 1,000 subsequently. A development agreement for the most ambitious and transformative part of the regeneration involved a lead private developer building under licence with the council and Optima as partners. After 10 years, 275 houses and 402 flats had been completed for social rent and a further 25 houses and 45 flats for shared ownership. Continuity in external designs made it hard to identify the tenure of properties: most new houses were rented from Optima, and most new private dwellings were flats. The clearance and demolition programme had been completed along with substantial new building when the credit crunch affected private sales: the developer stopped building for sale in 2008 and it was 2 years before construction restarted. Two blocks of apartments, held at shell construction stage pending sales, were sold to Optima as additional social housing, at below 50\% of 
(a)

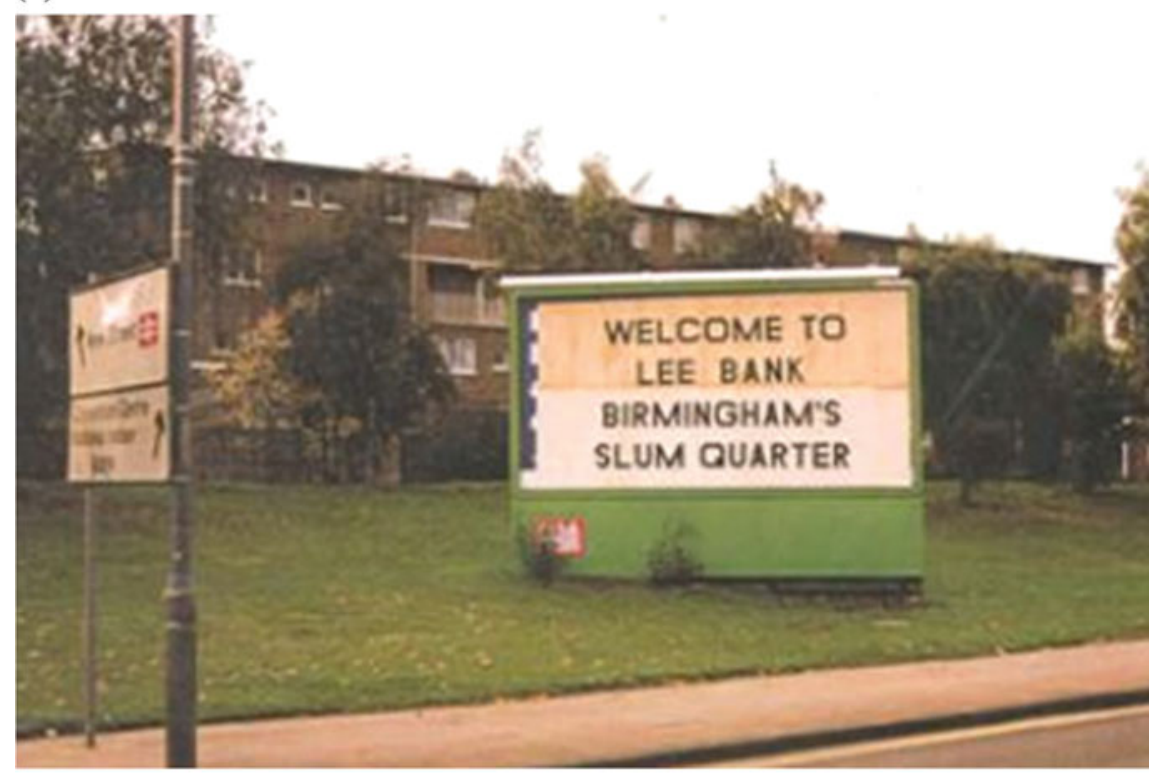

(b)

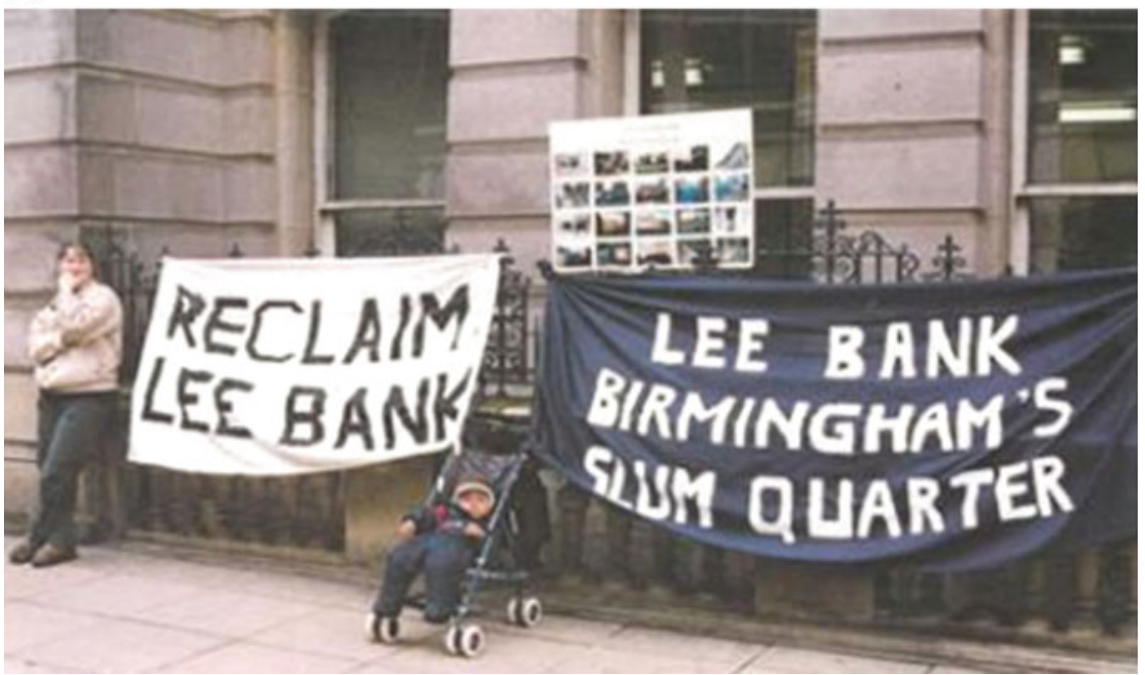

Fig. 6.6 a Residents' protests on Bristol Street, late 1990s, Lee Bank, Birmingham b Residents' protests outside the Council Offices, late 1990s, Lee Bank, Birmingham.

Source Birmingham Library Archives and Optima Community Association, used with permission 


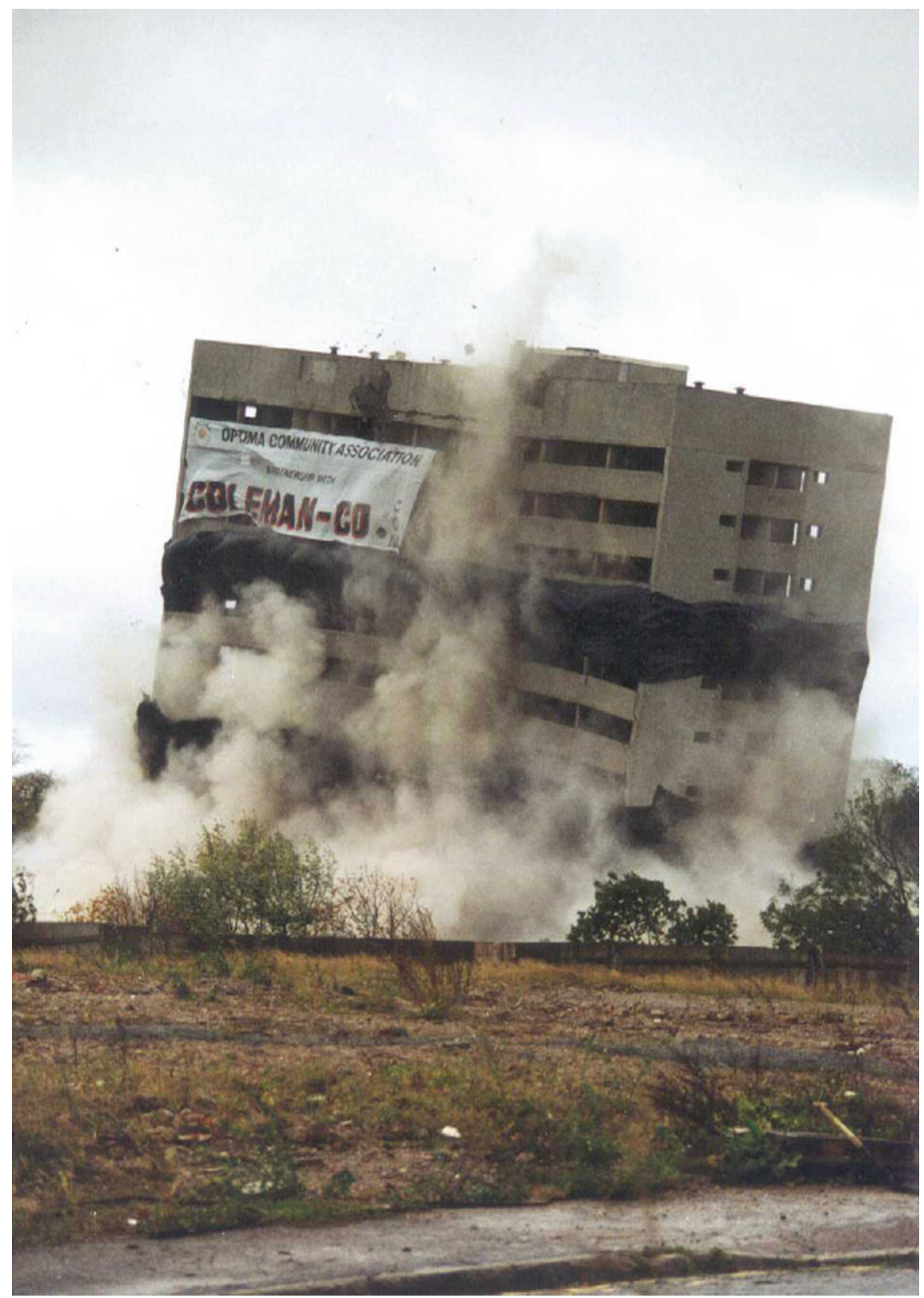

Fig. 6.7 Explosive demolition of Haddon Tower, Lee Bank, Birmingham. Source Birmingham Library Archives and Optima Community Association, used with permission 


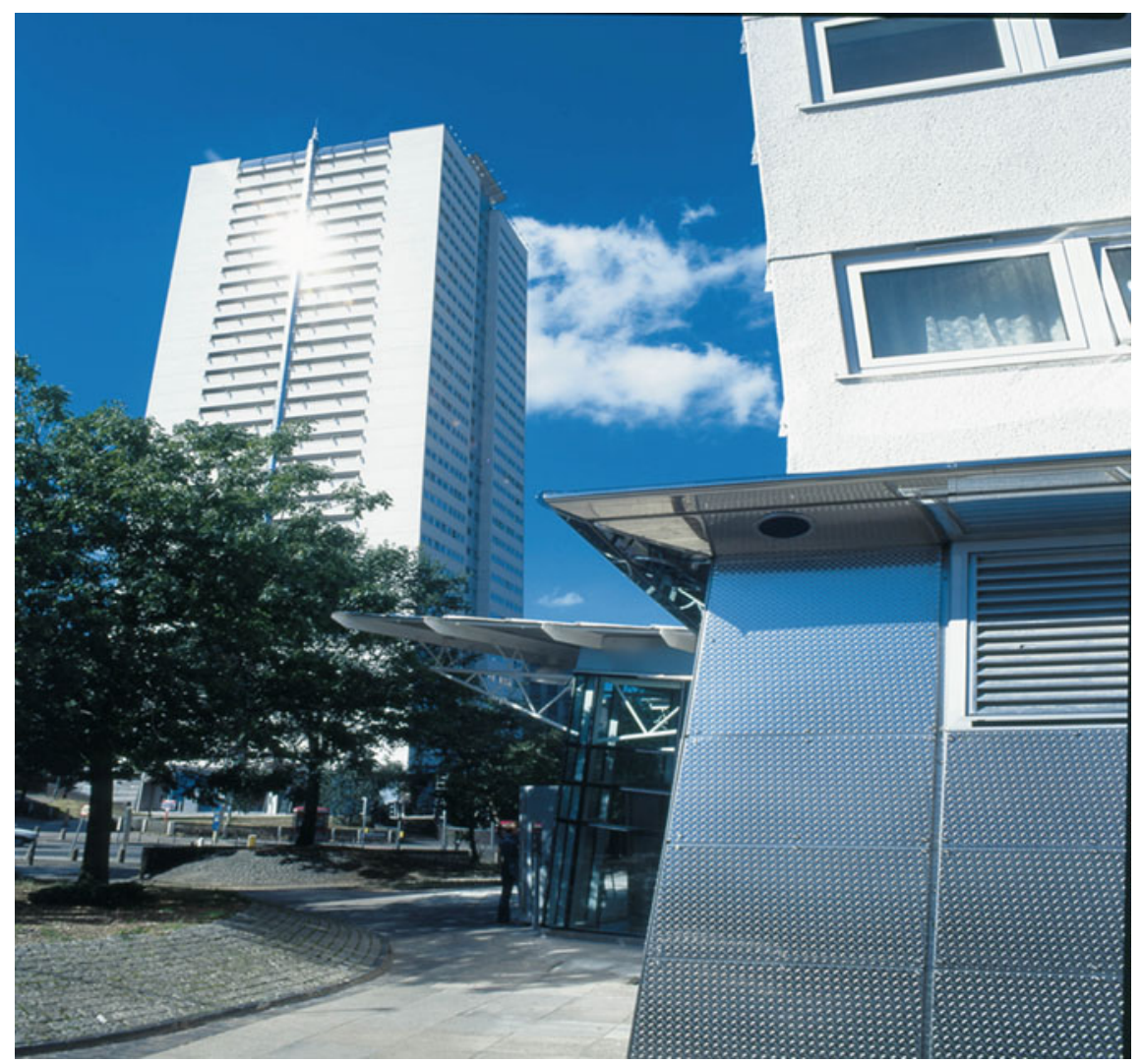

Fig. 6.8 The Sentinels (32-storey blocks) following refurbishment. Source Birmingham Library Archives and Optima Community Association, used with permission

the intended private sale price and with grant funding as government sought to deal with problems arising from the credit crunch. Importantly, the developer did not cease trading and continuity of their personnel (and Optima and city council personnel) sustained the underlying strategy.

By 2017, regeneration of the Central Estates was almost complete. It had taken longer than planned, but the ambitions in terms of quality of housing, tenure mix, new parks, shops, community, school and health facilities and commercial office accommodation were largely achieved. Modernised social rented housing included houses and a greater mix of flats. Building properties for sale completed the transformation from a residential council estate to a mixed-use, mixed-tenure estate. The transformation was achieved through joint action by the state and private sectors, and legitimate questions arise about winners and losers, and whether regeneration was simply planned gentrification and whether improvements were sustainable. 


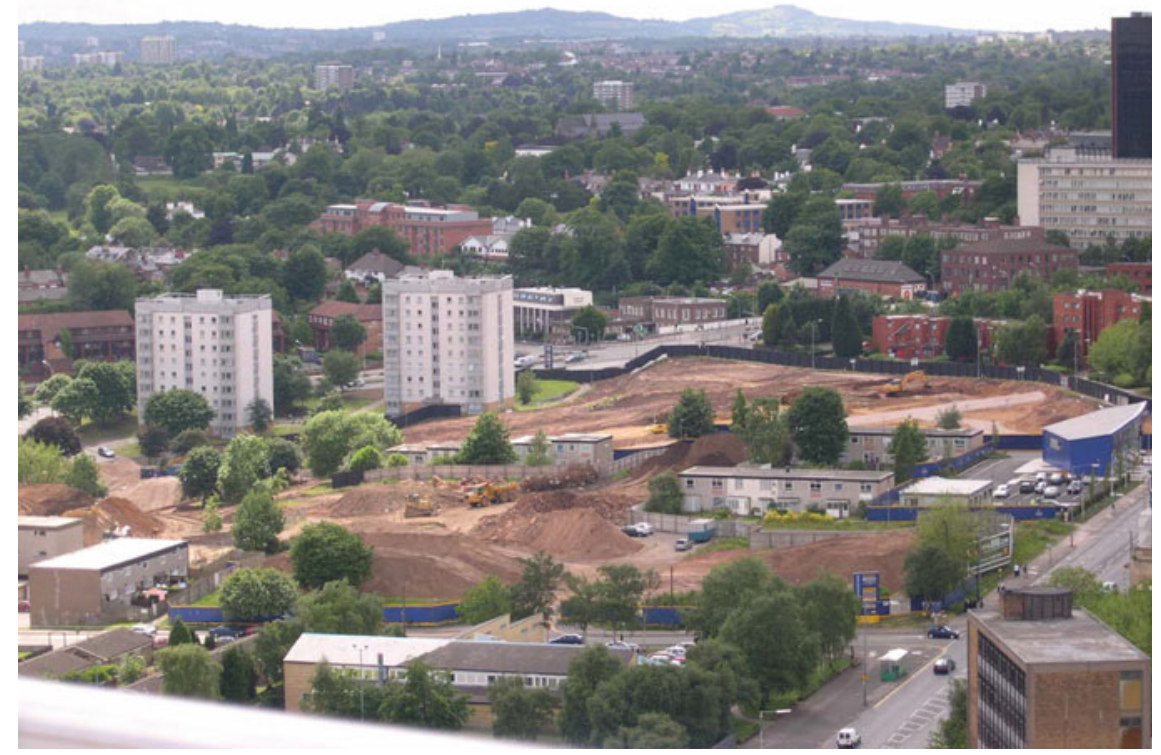

Fig. 6.9 Refurbished tower blocks alongside cleared sites being prepared for new parks and new mixed-tenure housing. Source Birmingham Library Archives and Optima Community Association, used with permission

Lees (2008) suggested that regeneration initiatives fail to improve the quality of life for neighbourhood residents and involve gentrification with 'overwhelmingly negative effects', particularly through displacing low-income groups. This does not hold for the Central Estates. They were in progressive decline and regeneration involving demolition and major capital investment represented an expensive change in approach. Continuing neglect would have further damaged the neighbourhood and prepared the ground for wholesale redevelopment or privatisation. Doing nothing would not have defended residents or public sector housing or prevented eventual gentrification. In the Central Estates, residents' opposition to doing nothing was the catalyst for regeneration, demolition and tenure diversification. These were each regarded positively as changing neighbourhood dynamics: building private housing also generated funds for social housing renewal.

A critical test is whether existing residents benefitted or were displaced. Refurbishment did not require tenants to move out but demolitions involved 1400 properties. Their tenants received Home Loss and Disturbance Payments and gained priority in social housing allocations on the estate and across the city. Where residents in properties being demolished wanted to stay in the area, but could not stay because no suitable properties were available, they could register their wish to return. Households on this 'returners' list had priority for subsequent social housing 
vacancies in the area, including new properties. By mid-2006, all registered 'returners' had returned: everybody forced to move but wanting to move back had done so. In some cases, where the opportunity to move back was not exercised, clearance had enabled households to move and find satisfactory housing elsewhere. The conclusion that there was little or no direct displacement reflects a managed and regulated regeneration process with strong resident scrutiny. The state and private sectors were involved in regeneration to pursue their own interests but there were real material gains for existing residents rather than wholly negative outcomes. Regeneration delivered benefits to local and lower income people. Before the regeneration commenced, there were high levels of vacant homes and tenancy turnover-both indicating the unattractiveness of the estate and failures of management. In 1998 , over $20 \%$ of properties were vacant and in $2000 / 01,17 \%$. The annual tenancy turnover rate was also over $20 \%$.

Were improvements sustained or did problems re-emerge? By 2017, some of the earliest investments had been completed 15 years earlier-but construction was still underway on the last development site. Assessing the sustainability of improvements remains difficult but reduced levels of abandonment, turnover and empty properties had been sustained. There were 46 abandonments in 2001/02, 29 in $2002 / 03$, and four, nine and four in the following 3 years, and they remained low with only one property abandoned in 2016. High demand was also sustained beyond the regeneration phase and turnover of properties declined from over $11 \%$ in $2001 / 02$ to $6 \%$ in $2015 / 16$. Transfer to a housing association headed off the risk that property problems would emerge without resources to remedy them: by 2017 , an asset management strategy was working and funding for a 20-year kitchen and bathroom replacement programme and the expensive and complicated replacement of soil and vent pipes in tower blocks.

The Central Estates were selected for regeneration partly because of high levels of deprivation, and funds were explicitly used to improve social and economic circumstances. Success in this area is difficult to evaluate and complicated by population change. Rent arrears' levels had improved but remained above those in some parts of Birmingham because of the large numbers of tenants in and out of work, or in low-paid jobs. There was a slowly rising trend in the proportion of new tenants that were from black and minority ethnic groups. In the financial year 2015/ $16,72 \%$ of new tenants were black and minority ethnic households compared with $52 \%$ in $2003 / 04$, and $62 \%$ in $2005 / 06$. As in the past, the vast majority of lettings were made to residents under the age of 45 .

Regeneration of the Central Estates was facilitated by continuities in personnel and policy. But, however well planned and intentioned the regeneration was and however effectively it represented residents' demands, unanticipated changes put it at risk. Implementation of the regeneration strategy was interrupted by planning disputes and problems over commercial premises but, more importantly, by the credit crunch in 2007 and by changes in government's approach to benefits. The Welfare Act 2012 was designed to reduce the welfare budget nationally. In the central estates, reductions in housing benefits (including cases where tenants were deemed to have spare rooms) undoubtedly affected working age tenants: some 
accepted transfers to smaller properties to reduce housing costs but the majority coped in other ways. The pressure on household budgets affected the sustainability of regeneration with changes that could force some residents to move and some tenancies to fail. Reduced benefits for people under 35 years old also affected the affordability and lettability of one-bedroom flats in tower blocks and the successful policy to not house families in tower blocks was, consequently, changed.

The regeneration programme for the Central Estates supported higher staffing levels and closer engagement with residents. Optima as a regeneration vehicle with its own staff developed its own culture, reflected in the participation of residents and attention to strategy and detail over major investments and routine management. However, once demolition, refurbishment and new building were completed, existing levels of staffing could not be supported by the residual budget. With government and the regulator convinced about economies of scale and maintaining a patronising disposition, rather than valuing accountability to tenants, there was pressure for Optima to become part of a larger group of housing associations. Whatever its other merits, acceding to this pressure diluted local resident involvement and accountability.

\subsection{Conclusion}

Estates built in the mass housing era have not stood the tests of time as well as traditionally built council estates. What happened to them was not, however, simply a consequence of design and construction or even of life cycle processes of obsolescence and population ageing. Estates were also affected by economic and social changes, the residualisation of council housing and the promotion of private housing. Mass estates became among the least attractive parts of what increasingly became a residual council tenure - a double residualisation. Many estates, including the Central Estates, were in decline. In the Central Estates, action by residents and the city council accessed funds and enabled regeneration that benefitted existing and new residents. The modernised estate had more social and tenure mix and more middle-class households, but because of the amount of additional housing rather than displacement. It also improved the quality and variety of social housing and improved energy efficiency, in new and refurbished social housing, benefitted tenants. The estate continued to house tenants from black and minority ethnic groups and low-income households, but in better housing than previously. Regeneration did not involve displacement, improved residents' living conditions and favourably changed the estate's trajectory. It was a better response to decline than doing nothing and leaving the way open for privatisation and regeneration driven by different interests, with less concern for avoiding displacement, improving social housing and changing neighbourhood facilities and dynamics.

Contextual changes, demolition, privatisation and regeneration initiatives have variously and unevenly transformed mass public estates. Some 50 years after construction, estates are very different than at the outset. Their transformation 
results from factors, layered upon each other, that were more or less important in different places. For example, some estates were severely damaged by local factory closures; others were affected by design and construction failures and associated high turnover. Different starting points (location, design and construction), life cycle changes (the deterioration of physical fabric and changing population), economic and social developments, management and maintenance practices and regeneration and renewal responses interacted with each other. While the first two of these suggest some intrinsic characteristics affecting how estates evolved, the latter two emphasise social and political action. Distinctive characteristics of mass estates generated different risks and contingencies than traditional estates, but did not determine their history.

A life cycle account highlights changes over time rather than physical characteristics. Estates that were generally popular at the outset lost popularity and reputation through obsolescence, failures of management and maintenance and changing contexts. Mass housing proved less sustainable than single-family dwellings and many estates soon needed costly, estate level, regeneration. When and how regeneration was conducted affected who benefitted and reset the starting position for the next phase of their life cycle. But whatever the potential, following regeneration, what actually happens depends upon policies, political action and social and economic changes.

The role of mass public housing estates has changed dramatically. When they were built they formed part of a privileged, high demand, high standard tenure. While not all mass housing became unpopular and not all traditional council housing remained popular, by 2017 mass estates were often stereotypically portrayed as dysfunctional areas for homeless and vulnerable households, new migrants and ethnic minorities. Their residents risked being denigrated and demonised because of their incomes, immigrant status, ethnicity or status as social tenants. The politics of race and migration and neo-liberal attitudes to poverty and welfare formed a further layer affecting estates. The estates did not, however, provide the only housing for marginal groups. Other social housing as well as home ownership housed lower income households and, for many of the most vulnerable, new migrants and younger single people, poor quality privately renting was most accessible.

A layered and life cycle approach highlights changes over time and differences between estates. It suggests three different ideal types among estates:

- Estates that were 'built to fail' - so flawed by their scale, design, construction and layout that they were bound to fail.

- Estates that were 'failed by management' - where neglect, management and maintenance failures and restrictions on expenditure prevented appropriate responses to initial problems and challenges associated with economic and social change.

- Estates that were potentially 'resilient'-where locational and other factors sustained demand. 
Each of these ideal types has been exposed to decline with the passage of time but they map on to two strategic responses: renewal and redesign, and better management. In practice, both better management and new capital expenditure have been necessary but not always sufficient for sustainability. Where estates have not been demolished, major refurbishment has been critical. The discussion of the Central Estates highlighted factors making refurbishment work-including residents' involvement, the organisations and partnerships involved, significant government funding and continuity and commitment of professional staff working locally. Some elements are less visible-locational advantage and regulatory control. Other elements potentially put refurbishment at risk - privatisation, deregulation, wider economic fluctuations, organisational change, loss of local control and disrespectful treatment of marginal groups.

Responses to the decline of mass estates have variously involved minimal action (unmodernised estates continuing to adversely affect residents' health and well-being), renewal and refurbishment, and demolition. Whether regeneration involved displacement and gentrification or improved liveability and opportunities for existing residents is an empirical question, but reflects financial arrangements, political processes and social action. In some cases, refurbishments have failed other tests. The deaths of 71 people at Grenfell Tower in the London Borough of Kensington and Chelsea following a fire in June 2017 highlighted health and safety problems in refurbished tower blocks. Public and media debate about this catastrophe focussed on failures associated with funding, technical solutions, regulation, contracting, inspection and implementation of refurbishment. But underlying these failures was underfunding and neglect of social housing over decades and the treatment of marginal groups and ethnic minorities by some public and private sector agencies. Layered explanations for continuing failure must include these and other elements. Doing nothing, privatisation and regeneration that serves developers' interests (and involves displacement) and refurbishment all pose risks for residents. It is unclear whether increased awareness of failure will further damage the reputation of high-rise blocks, mass estates and public housing or will lead to increased funding, regulatory supervision and resident engagement that will improve estate futures.

Acknowledgements The author acknowledges assistance from the Birmingham Library Archives, the City of Birmingham and Optima Community Association

\section{References}

Cantle T (1986) The deterioration of public sector housing. In: Malpass P (ed) The housing crisis. Croom Helm, London, pp 57-85

Cooney EW (1974) High flats in local authority housing in England and Wales since 1945. Multi-Storey Living, Croom Helm, London

Dunleavy P (1981) The politics of mass housing in Britain, 1947-1975. Clarendon Press, Oxford Forrest R, Murie A (1990) Selling the welfare state, 2nd edn. Routledge, London 
Hall S, Lee P, Murie A, Rowlands R, Sankey S (2003) Large housing estates in united kingdom overview of developments and problems in London and Birmingham. Restate Report $2 \mathrm{~J}$. University of Utrecht, Utrecht

Hall S, Murie A, Knorr-Siedow T (2005a) Large housing estates in their historical context. In: van Kempen R, Dekker K, Hall S, Tosics I (eds) Restructuring large housing estates in Europe. Policy Press, Bristol, pp 63-84

Hall S, Murie A, Rowlands R, Sankey S (2005b) Large housing estates in London and Birmingham, United Kingdom, Opinions of Residents on recent developments. Restate Report 4j. University of Utrecht, Utrecht

Henderson J, Karn V (1987) Race class and state housing. Gower, London

Holmans AE (1987) Housing policy in Britain. Croom Helm, London

Jones CA, Murie A (1999) Stability and change in council estates: the right to buy. Hous Plann Rev 54(2):11-12

Lee P, Murie A (1997) Poverty, housing tenure and social exclusion. The Policy Press, Bristol

Lee P, Murie A (2002) The poor city: national and local perspectives on changes in residential patterns in the British City. In: Marcuse P, van Kempen R (eds) Of states and cities: a partitioning of urban space. Oxford University Press, Oxford

Lees L (2008) Gentrification and social mixing: towards an inclusive urban renaissance? Urban Studies 45(12):2449-2470

Murie A (2016) The right to buy?. Policy Press, Bristol

Rex J, Moore R (1967) Race, community and conflict. Oxford University Press, Oxford, Community and Conflict

Rex J, Tomlinson S (1981) Black immigrants and the housing system in Birmingham. In: Cochrane A, Hamnett C, McDowell M (eds) City economy and society: a comparative reader. Harper and Row, London

Rowlands R, Murie A (2009) Whose regeneration? The spectre of revanchist regeneration Palgrave. In: Rowlands R, Musterd S, van Kempen R (eds) Mass housing in Europe. Macmillan, Basingstoke, pp 235-264

Sutcliffe A (1974) A century of flats in Birmingham, 1875-1973. In: Sutcliffe A (ed) Multi-storey living. Croom Helm, London, pp 181-206

Sutcliffe A, Smith R (1974) Birmingham 1939-1970, History of Birmingham, vol 3. Oxford University Press, London

Open Access This chapter is licensed under the terms of the Creative Commons Attribution 4.0 International License (http://creativecommons.org/licenses/by/4.0/), which permits use, sharing, adaptation, distribution and reproduction in any medium or format, as long as you give appropriate credit to the original author(s) and the source, provide a link to the Creative Commons license and indicate if changes were made.

The images or other third party material in this chapter are included in the chapter's Creative Commons license, unless indicated otherwise in a credit line to the material. If material is not included in the chapter's Creative Commons license and your intended use is not permitted by statutory regulation or exceeds the permitted use, you will need to obtain permission directly from the copyright holder. 